\title{
Instrument Design of Assessment Performance for Sector Internal Retail in South Tangerang
}

\author{
Zahrida Wiryawan ${ }^{1, *}$ Rodhiah $^{2}$ \\ 1,2 Tarumanagara University \\ ${ }^{*}$ Corresponding author.Email: zahridaw@fe.untar.ac.id
}

\begin{abstract}
This study aims to provide an instrument assessment of internal performance factors in retail businesses in traditional markets in South Tangerang. The sample was chosen by purposive sampling as many as 210 retail traders in 7 traditional market locations. Simple random sampling is done in selected retailers in each market, each location is chosen from 20 to 30 retailers of fashion product categories. Development of assessment of performance instruments in the company has been carried out. However, the scale of the retail business is still rare. The research model referred to the performance assessment developed based on aspects of internal performance appraisal. Data collection techniques were done by observation, FGD, experts, and distributing questionnaires to retail entrepreneurs who were selected as sample members. The validity of the contents of the instruments was examined by asking for opinions from peers and several experts in retail marketing and management. The instrument was tested on retail entrepreneurs who became the study sample. Validity and reliability analysis used a confirmation factor with the help of LISREL software. The result showed that the internal performance assessment on HR dimensions or aspects showed that there were 11 instruments in measuring HR dimensions (all valid items). In financial dimensions or aspects, there were 6 instruments in measuring financial dimensions (1 invalid). In the technical operational dimensions or aspects are 7 statement items in measuring technical and operational dimensions ( 1 is invalid); on market dimensions or aspects and marketing showed that of the 6 instruments in measuring market and marketing ( 1 is invalid). Moreover, all instruments related to assessing the internal performance of the retail business are 30 instruments. Hence, the result of the research is expected to obtain an internal performance appraisal instrument model in Traditional market retail businesses that are ready to be implemented in the South Tangerang area.
\end{abstract}

\section{Keywords: Instruments, Performance Appraisal, Retail SMES, Business Sustainability}

\section{INTRODUCTION}

Indonesia has a huge traditional retail market and is spread almost in every location. The existence of a traditional market that has become a modern market or has not become a modern market has given effect to the economic life of the community. The development of the retail business increases every year. APRINDO [1] stated that the retail sector can reach 10 percent in 2017, he also stated that several factors affect the growth of the retail industry, as of November 2016, retailers' turnover reached Rp200 trillion. On the other hand, the development of the retail sector was triggered by the rise of modern retailers. Through Presidential Regulation No. 112 of 2007 concerning the Arrangement and Development of Traditional Markets, Shopping Centers and Modern Stores are intended to create harmony, mutual need, mutual reinforcement and mutual benefit between traditional markets and modern markets. Despite the government's efforts, inevitably the condition of the traditional retail market shows an increasingly conducive level of business competition, retailers face competitors not only among the retail market itself but the onslaught of modern markets that are increasingly widespread, even online shopping has affected progress and business continuity. Many retailers cannot carry out their activities. This condition is inseparable from poor business performance. For this reason, it is important for retailers to harmonize the factors that determine business performance through strategic performance assessment. Research from Rodhiah and Zahrida [2] on competing Grant Research and in line with Munizu [3] indicated that the performance appraisal model produces internal factors that include HR, financial aspects, operations and operations, markets and marketing. From each factor, an instrument needs to be developed that can be 
used as a benchmark in assessing retail business performance. While the hope of retail store owners can maintain business sustainability and overcome increasingly competitive competition problems.

Companies need to harmonize the factors that determine their performance with good strategic goals that have been documented in various works of literature [4]. Temtime and Pansiri [5] stated that 203 SMEs in Bosnia showed the results of his research that the factors of human resource development, organizational development, manager and the owner background, management leadership, and competitive strategies are important components that influence SME performance. Through the assessment of internal factors can be a trigger in increasing development and growth in the retail sector.

It is important to develop instruments in measuring performance appraisal in the traditional retail sector in the aspect of subjective assessment in the form of internal performance, considering that the traditional retail sector is very large and complex. The availability of retailers in the South Tangerang traditional market is very much and has not been well organized, including maintaining good business continuity for the owner, is a must. For this reason, research is focused on the scale of fashion retail business. Besides that, for every retail business, it is important to have quality standards that are measured in an instrument. So far there has been no uniformity in the size used.

Various internal performance assessment factors are important for retail entrepreneurs to assess business excellence. The result of the assessments can be the basis for retailers to be able to survive the onslaught of competitors. Moreover, retailers can survive and maintain business sustainability in the future. Concerning the results of previous studies and considering there are no standard measurements of performance appraisal. Every business has different sizes. Retailers need to improve business performance that can maintain business sustainability. To be able to survive long enough, retailers need to understand the measures that can be used in assessing business performance. For this reason, every retail entrepreneur has an internal performance assessment standard measured in an instrument. Hence, the problem in this research is how to map the performance conditions of SME Retail fashion products in the traditional markets of the South Tangerang region, because through initial observations it can be seen that this area has many traditional markets, which do not yet have good performance, so it needs to improve business performance; how to design retail business performance assessment instruments based on HR, financial, operational and market operations and marketing aspects and how to test internal performance appraisal instruments at traditional retailers. This study aims to examine and analyze the problems surrounding the development of retail business internal performance assessment instruments, namely: Making a mapping of the performance conditions of SME Retail fashion products in various Traditional Markets who designed performance appraisal instruments in retail businesses with categories of fashion products sold in Traditional markets based on internal performance assessments of HR, financial aspects, market operations and operations and marketing. The purpose of this study is to help retail business owners in having standardized performance assessment instruments, especially in the fashion retail sector. Furthermore, through these instruments, retail business owners can maintain business continuity and improve business performance in the future.

\section{LITERATURE REVIEW}

Every retailer needs to know the retail business performance that has been achieved. Hence, retailers can choose the size they feel is most suitable in retail business activities, to assess the extent to which the results of their business performance are achieved. According to the literature, small and medium enterprises need a simple performance system. Provides focused, clear and useful information management. Chen [6] defined that performance management is a process in which managers and employees reach a consensus on responsibilities, goals, and how to achieve and also the process of strengthening employee practical management and driving to gain excellent performance. Rivai [7] suggested that performance is the appearance of the company's condition as a whole for a certain period as a result or achievement that is influenced by operational activities of resource utilization [7]. [8] indicated that performance is the achievement of the activities of a company through the strategic activities that have been carried out in achieving the planned goals. [9] stated that company performance is a construct that is generally used to measure the impact of a company's strategic orientation. Company performance is something that is produced by a company in a certain period regarding the standards set. Various works of the literature suggested a measure of performance that can be used as a standard for business. [10] suggested that financial profitability and growth as a measure that is often used to measure organizational performance.

Each retailer needs to know the size of the retail business performance that has been achieved. Meanwhile, retailers can choose the size they feel is most suitable in retail business activities, to be able to assess the extent to which performance achievements that have been obtained from the results of their efforts in increasing competitive advantage.

The Research Model can be illustrated in the following figure: 


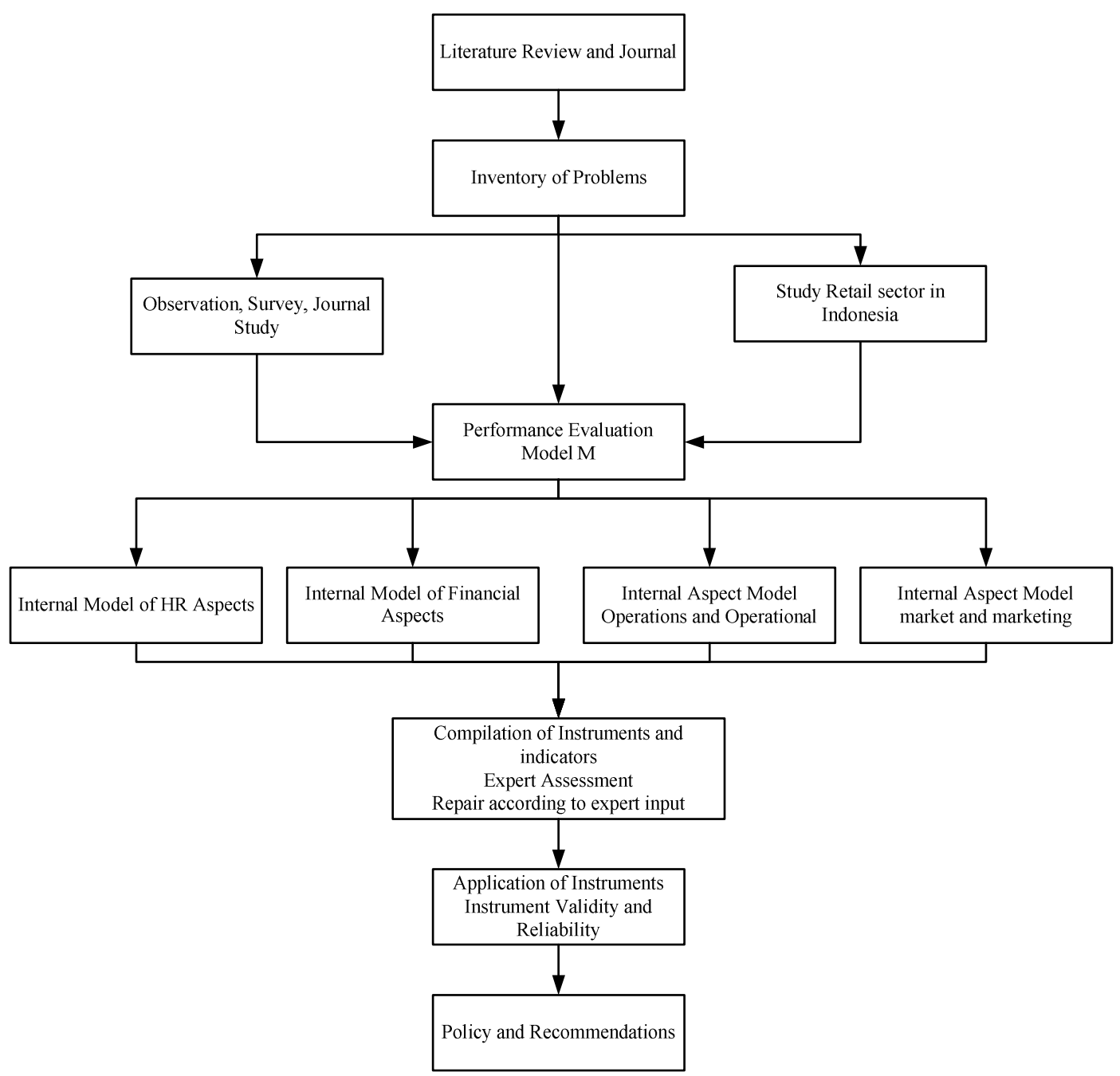

Figure 1 Research Model

\section{METHODS}

Identification of research aspects with the location of research as in table 1 below

Table 1. Research Aspects and Locations

\begin{tabular}{|c|c|c|}
\hline No & Research Aspect & $\begin{array}{l}\text { Research } \\
\text { Location }\end{array}$ \\
\hline & $\begin{array}{l}\text { a) Traditional market studies in } \\
\text { the city of Tangerang } \\
\text { b) Theoretical studies and } \\
\text { previous research regarding } \\
\text { performance assessment } \\
\text { factors } \\
\text { c) Describe the research } \\
\text { subjects based on age, } \\
\text { education, business scale, } \\
\text { length of business, the form } \\
\text { of business, number of } \\
\text { employees, types, forms, }\end{array}$ & $\begin{array}{c}\text { South } \\
\text { Tangerang } \\
\text { which } \\
\text { includes retail } \\
\text { businesses in } \\
\text { fashionable } \\
\text { fields in } \\
\text { traditional } \\
\text { markets such } \\
\text { as Jombang } \\
\text { market, } \\
\text { Serpong, }\end{array}$ \\
\hline
\end{tabular}

\begin{tabular}{|l|l|c|}
\hline retail categories, business & Modern BSD \\
units, skills/abilities of & City, Bintaro \\
retailers, community culture, & Modern Jaya \\
others & Simpasa, \\
d) Study of performance & Delapan \\
evaluation of each retail & Sutera, \\
store & Paramount \\
e) Preparation of instruments & market, \\
f) Enter instruments from & Ciputat \\
experts & market. \\
g) Repair of instruments & \\
according to experts & \\
h) Assessment of instrument & \\
content validity according to & \\
expert input
\end{tabular}

The study was conducted at retail stores in the traditional market as many as 8 markets in the South Tangerang region 
such as Jombang market, Serpong, Modern BSD City, Modern Bintaro Jaya Simpasa, Delapan Sutera, Paramount market, Ciputat market. Furthermore, it was selected by sample with a simple random technique of 210 retailers of fashion products at the 8 market locations. This research activity includes:

Table 2. Research Activities

\begin{tabular}{|c|c|c|c|}
\hline Year I & Type of activity & Activity & Activity Result \\
\hline \multirow{5}{*}{$\begin{array}{c}\text { Activities carried } \\
\text { out }\end{array}$} & Survey & Observation, interview, FGD & \multirow{5}{*}{$\begin{array}{c}\text { - Primary data and } \\
\text { secondary data to } \\
\text { design a retail } \\
\text { business } \\
\text { performance } \\
\text { evaluation model } \\
\text { - Design a model for } \\
\text { evaluating retail } \\
\text { business } \\
\text { performance in } \\
\text { traditional markets }\end{array}$} \\
\hline & Mapping & $\begin{array}{l}\text { - Record traditional market } \\
\text { locations that have been and } \\
\text { have not been revitalized } \\
\text { - Record the use of types of } \\
\text { instruments to improve retail } \\
\text { business performance }\end{array}$ & \\
\hline & Literature Study & Arrange Draft Instruments & \\
\hline & expert justification & $\begin{array}{l}\text { Validate the contents of the } \\
\text { instrument based on the } \\
\text { results of the experiment }\end{array}$ & \\
\hline & $\begin{array}{l}\text { - Design of Instrument Models } \\
\text { - Test of Instrument Design } \\
\text { performance appraisal before } \\
\text { implementation to retail store } \\
\text { owners }\end{array}$ & Test of Instruments & \\
\hline
\end{tabular}

\subsection{Measurements}

In conducting performance appraisal on retail business owners, assessment instruments are:

Table 3. Dimensions and Indicators

\section{A. Dimensions of Human Resources (HR)}

1. An educated business owner

2. The leader has a leadership spirit

3. Business owners have experience

4. Skilled business leaders in managing stores

5. Shop owners are skilled in managing employees

6 . The number of store employees according to the needs of the store

7. Educated employees

8. High motivation employees

9. Employees have sales skills

10. Employees have consumers' serves

11. Payment of employee salaries on time

\section{B. Financial Dimensions}

12. Business capital comes from personal capital

13. No business capital loan

14. Daily profit calculation once a week

15. Capital returns take in time
16. Determination of product prices $25 \%$ of business capital

17. Fulfill all obligations on time

18. The level of profit according to the target

C. Technique and Operational

19. Have store inventory

20. Monitor the inventory

21. Available items are always sold out

22. Availability of cashier machines or payment instruments

23. Attract attention to product displays

24. Product display according to store size

25. Ease of using debit or credit payment tools

26. Cooperation with online payment instruments

\section{Market and Marketing}

27. Selling products that are trends in the community or not in the market

28. Market demand exceeds competitors

29. Market visitors are crowded

30. Competitive product prices

31. Quality products

32. A sales promotion

33. Using online promotional media 
The research uses the Likert scale with 7 response options. The score is 1 (very disagree) to 7 (very agree).

\subsection{Validity and reliability analysis.}

Validity and reliability are analyzed in terms of variables, dimensions and items. In this study, the validity and reliability of the instrument were carried out using confirmatory factor analysis (CFA). The questions in each dimension are valid if they have a loading factor value of $>0.5$, then the research instruments in each dimension are declared reliable if they have AVE values $>0.5$ and $C R>0.7$. [11].

\subsection{Analysis}

LISREL 8.8 software is used to analyze validity and reliability of the instrument.

\section{RESULTS AND DISCUSSIONS}

Performance appraisal instruments on the HR dimension will be shaped as follows:

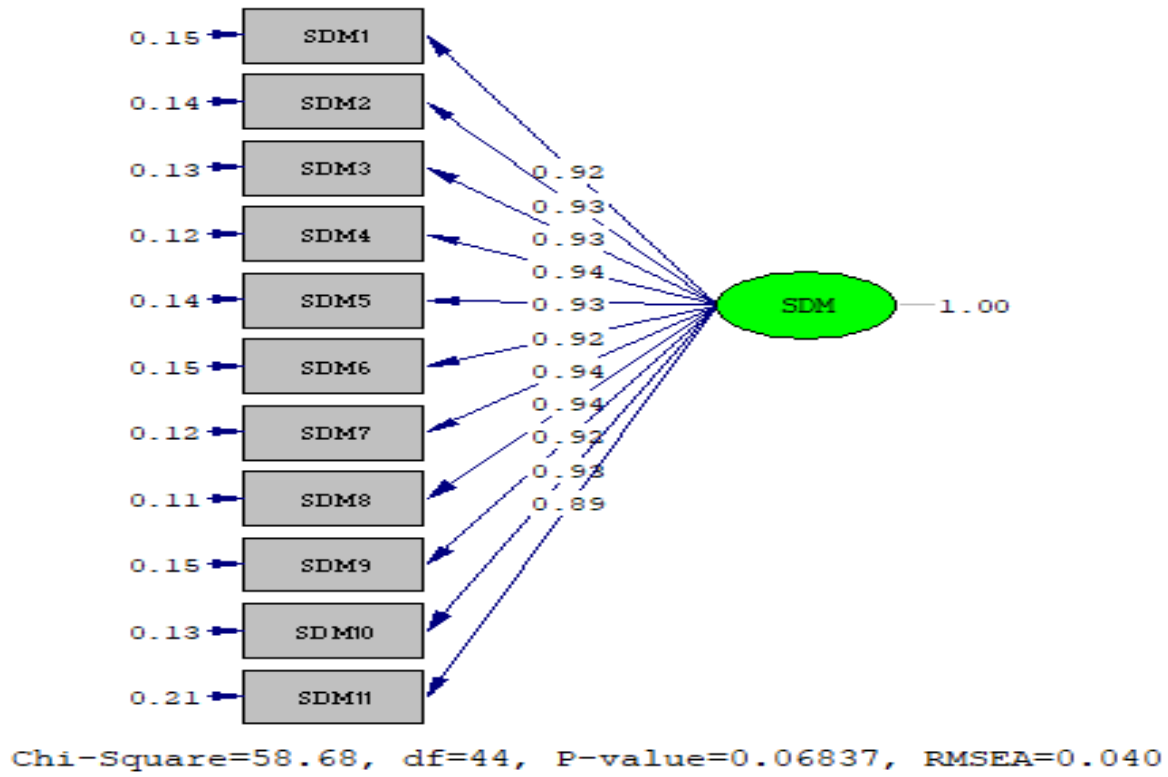

Figure 2 CFA Model Specifications HR Performance Dimensions Variables

Table 4. Test Result for the Validity of Instrument Performance Variables in the HR Dimension

\begin{tabular}{|c|c|c|c|}
\hline Indicator & Loading Factor & Cut Value & Validity \\
\hline HR1 & 0,92 & 0,5 & valid \\
\hline HR2 & 0,93 & 0,5 & valid \\
\hline HR3 & 0,93 & 0,5 & valid \\
\hline HR4 & 0,94 & 0,5 & valid \\
\hline HR5 & 0,93 & 0,5 & valid \\
\hline HR6 & 0,92 & 0,5 & valid \\
\hline HR7 & 0,94 & 0,5 & valid \\
\hline HR8 & 0,94 & 0,5 & valid \\
\hline HR9 & 0,92 & 0,5 & valid \\
\hline HR10 & 0,93 & 0,5 & valid \\
\hline HR11 & 0,89 & 0,5 & valid \\
\hline
\end{tabular}

Table 5. Test Result Instrument Reliability Performance of HR Dimensions

\begin{tabular}{|c|c|c|c|c|c|c|}
\hline $\begin{array}{l}\text { Dimen } \\
\text { sions }\end{array}$ & Indicator & $\lambda$ & $\begin{array}{c}\text { Validit } \\
y\end{array}$ & AVE & CR & $\begin{array}{c}\text { Reliabilit } \\
\text { y }\end{array}$ \\
\hline \multirow{11}{*}{$\begin{array}{l}\text { Hum } \\
\text { an } \\
\text { Reso } \\
\text { urces } \\
\text { (HR) }\end{array}$} & HR1 & 0.920 & valid & \multirow{11}{*}{0.858} & \multirow{11}{*}{0.990} & \multirow{11}{*}{ reliable } \\
\hline & HR2 & 0.930 & Valid & & & \\
\hline & HR3 & 0.930 & Valid & & & \\
\hline & HR4 & 0.940 & Valid & & & \\
\hline & HR5 & 0.930 & Valid & & & \\
\hline & HR6 & 0.920 & Valid & & & \\
\hline & HR7 & 0.940 & Valid & & & \\
\hline & HR8 & 0.940 & Valid & & & \\
\hline & HR9 & 0.920 & Valid & & & \\
\hline & HR10 & 0.930 & Valid & & & \\
\hline & HR11 & 0.890 & Valid & & & \\
\hline
\end{tabular}


Instrument performance appraisal on the financial dimension in the form of:

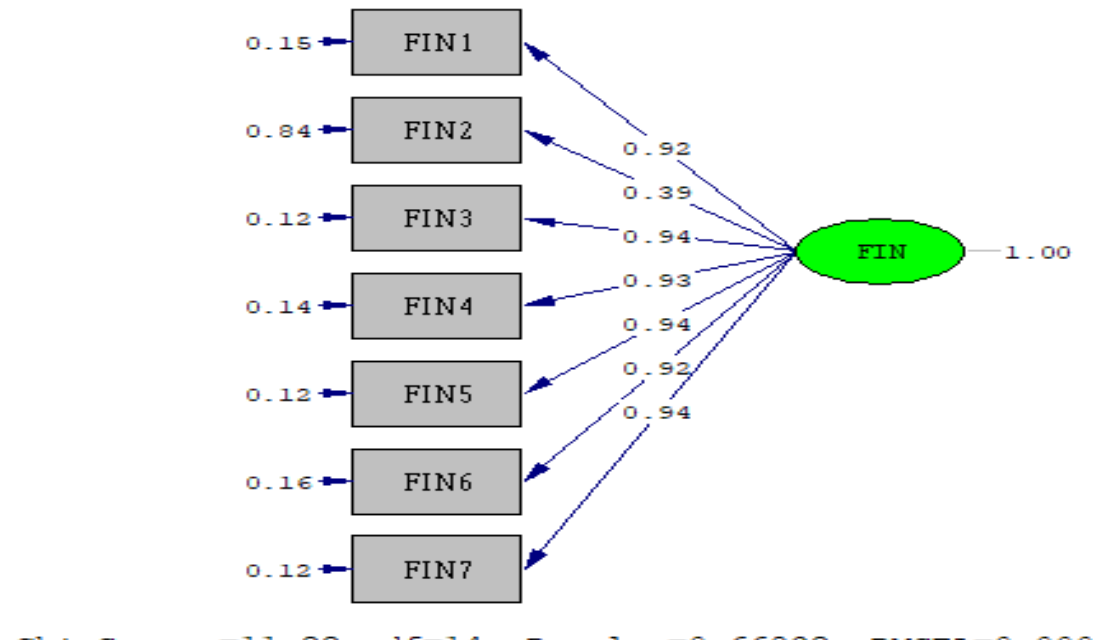

Figure 3 Variables of CFA Model Specifications Financial Dimension Performance

Table 6. Validity Test Result of Performance Assessment Instruments in Financial Dimensions

\begin{tabular}{|c|c|c|c|}
\hline Indicator & Loading Factor & Cut Value & Validity \\
\hline FIN1 & 0,92 & 0,5 & valid \\
\hline FIN3 & 0,94 & 0,5 & valid \\
\hline FIN4 & 0,93 & 0,5 & valid \\
\hline FIN5 & 0,94 & 0,5 & valid \\
\hline FIN6 & 0,92 & 0,5 & valid \\
\hline FIN7 & 0,94 & 0,5 & valid \\
\hline
\end{tabular}

Table 7. Test Reliability of Instrument Financial Dimension Performance Variables

\begin{tabular}{|c|c|c|c|c|c|c|}
\hline $\begin{array}{c}\text { Dimen } \\
\text {-sion }\end{array}$ & $\begin{array}{c}\text { Indi- } \\
\text { cator }\end{array}$ & $\lambda$ & Validity & AVE & CR & $\begin{array}{c}\text { Relia- } \\
\text { bility }\end{array}$ \\
\hline \multirow{4}{*}{$\begin{array}{c}\text { Finan } \\
\text {-cial }\end{array}$} & FIN1 & 0.920 & valid & & & \\
\cline { 2 - 4 } & FIN3 & 0.940 & valid & & & \\
\cline { 2 - 4 } & FIN4 & 0.930 & valid & \multirow{4}{*}{0.868} & \multirow{2}{*}{0.969} & reliable \\
\cline { 2 - 5 } & FIN6 & 0.940 & valid & & & \\
\cline { 2 - 5 } & FIN7 & 0.920 & valid & & & \\
\cline { 2 - 4 } & FIN & valid & & & \\
\hline
\end{tabular}

Performance appraisal instruments in dimensions of technique and Operational in the form of:

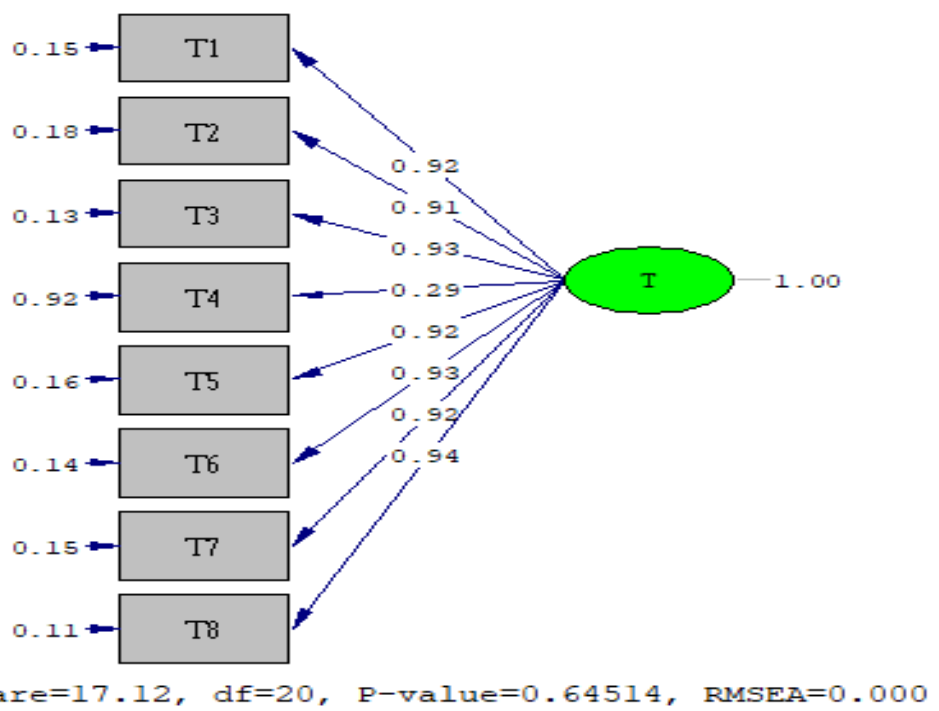

Figure 4 CFA Model Specifications Of Dimensions Technique And Operational 
Table 8. Validity Test Result of Dimension Instrument and Operational

\begin{tabular}{|c|c|c|c|}
\hline Indicator & Loading Factor & Cut Value & Validity \\
\hline T01 & 0,92 & 0,5 & valid \\
\hline T02 & 0,91 & 0.5 & valid \\
\hline T03 & 0,93 & 0,5 & valid \\
\hline T05 & 0,92 & 0,5 & valid \\
\hline T06 & 0,93 & 0,5 & valid \\
\hline T07 & 0,92 & 0,5 & valid \\
\hline T08 & 0,94 & 0,5 & valid \\
\hline
\end{tabular}

Table 9. Test Result Reliability of Dimension Instrument and Operational

Performance appraisal instruments in the Dimensions of Market and Marketing in the form of:

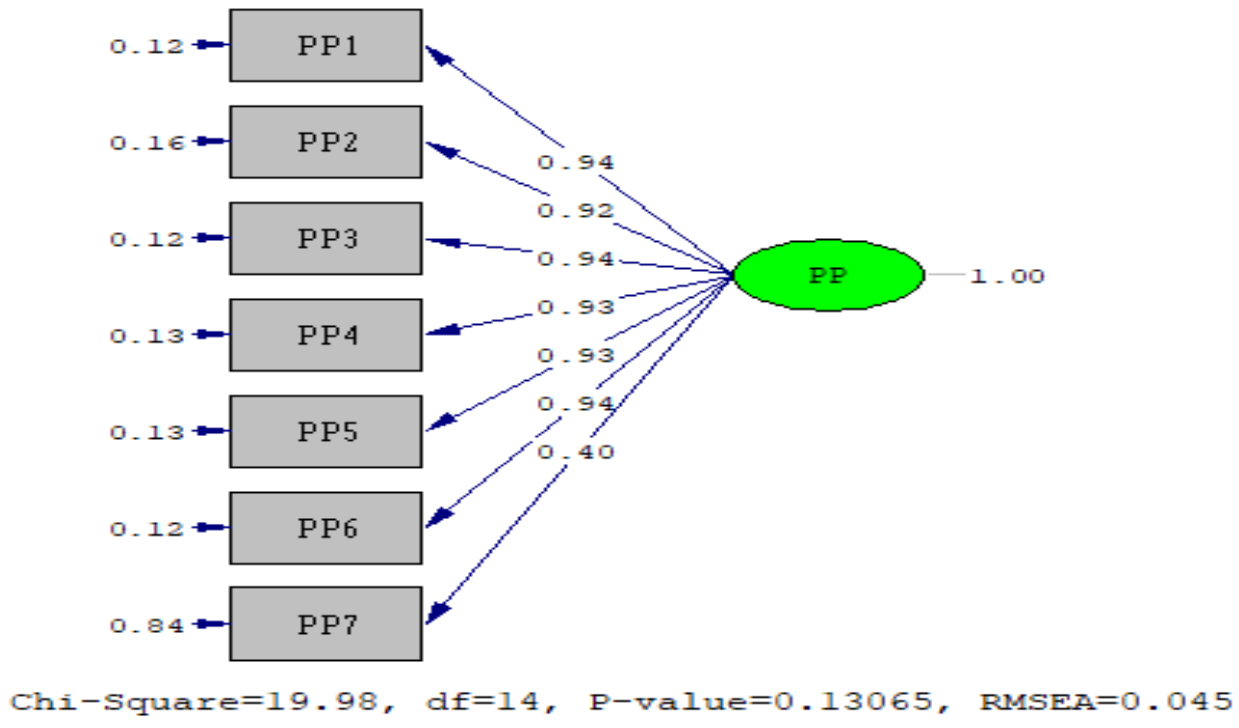

Figure 5 CFA Model Specifications in the Dimensions of Market and Marketing

Table 10. Test Result for Validity of Performance Instruments Variable in the Dimensions of Market and Marketing

\begin{tabular}{|c|c|c|c|}
\hline Dimensions & Indicator & Cut Value & Validity \\
\hline PP1 & 0.94 & 0.5 & valid \\
\hline PP2 & 0.92 & 0.5 & valid \\
\hline PP3 & 0.94 & 0.5 & valid \\
\hline PP4 & 0,93 & 0.5 & valid \\
\hline PP5 & 0.93 & 0.5 & valid \\
\hline PP6 & 0.94 & 0.5 & valid \\
\hline
\end{tabular}

\begin{tabular}{|c|c|c|c|c|c|c|}
\hline $\begin{array}{c}\text { Dimensi } \\
\text { on }\end{array}$ & $\begin{array}{c}\text { Indicat } \\
\text { or }\end{array}$ & $\Lambda$ & $\begin{array}{c}\text { Validit } \\
y\end{array}$ & AVE & CR & $\begin{array}{c}\text { Reliabili } \\
\text { ty }\end{array}$ \\
\hline \multirow{7}{*}{$\begin{array}{c}\text { Techniq } \\
\text { ue and } \\
\text { Operatio } \\
\text { nal }\end{array}$} & T01 & 0.920 & valid & \multirow{7}{*}{0.854} & \multirow{7}{*}{0.977} & \multirow{7}{*}{ reliable } \\
\hline & TO2 & 0.910 & Valid & & & \\
\hline & TO3 & 0.930 & Valid & & & \\
\hline & T05 & 0.920 & Valid & & & \\
\hline & T06 & 0.930 & Valid & & & \\
\hline & T07 & 0.920 & Valid & & & \\
\hline & T08 & 0.940 & Valid & & & \\
\hline
\end{tabular}


In the dimension of $\mathrm{HR}$, all statements are proven valid and can be used to measure performance on the HR dimension. The evidenced by the reliability of the dimensions construct which is shown that the AVE value of 0.858 and CR of 0.990 with the loading factor of all indicators $>0.5$. As [12] results of his research show the factors of human resource development, organizational development, manager / owner background, management leadership, and competitive strategy are important components that affect the performance of SMEs.

In the financial performance appraisal instrument, the results of the validity and reliability tests indicated that of the 7 item statements contained in the instrument, statement number 2 has a loading factor below 0.5 this indicated that statement number 2 cannot be used as a research instrument, hence, the number of statement items in the financial dimension performance variable is only 6 statements. Instrument reliability by including these 6 statements is appropriately good, namely with AVE values of 0.868 and $C R$ of 0.969 . As [10] suggests financial profitability and growth as a measure often used to measure organizational performance.

In the dimensions of Technique and Operations, from the 8 items of statements contained in the instrument, 1 indicator is declared invalid because it has a loading factor below 2, it is the T4 indicator. Thus, this instrument will only contain 7 statements with fairly good reliability, the AVE of 0.854 and CR of 0.977. As [13] the technical and operational dimensions support the performance of a business

In the dimensions of Market and Marketing, the test result of validity and reliability showed that of the 7 item questions in this instrument, there is 1 item statement that has a loading factor below 0.5 which is item statement number 7, whilst this instrument will only contain 6 statements with construct reliability is quite good, namely AVE value of 0.871 and CR of 0.969 . As [3] states that market and marketing factors have a significant and positive influence on the performance of micro and small businesses.

\section{CONCLUSION}

From the results of the analysis and discussion of the research, several conclusions can be made: Based on internal performance appraisal on HR dimensions or aspects, it showed that out of 11 questions in the instrument, all question items in the internal performance instrument are valid in measuring HR dimensions. Based on the assessment of internal performance on the financial dimension or aspect showed that of the 7 statements contained in the instrument, there is one instrument that is invalid so that the financial dimension is only 6 statements in the internal assessment instrument measuring the financial dimension Based on internal performance appraisal on technique and operational dimensions or aspects, fit showed that out of the 8 item statements contained in the instrument, there is one invalid instrument, the number of statement items on the dimensions of performance variables of technique and operational is only 7 statements in the internal assessment instrument valid in measuring dimensions of technique and operational

\section{REFERENCES}

[1] APRINDO, Pertumbuhan Ritel Akan Lebih Baik Tahun 2017, 2012

[http://www.aprindo.org/aprindo/home.do, accessed on November 4th, 2018]

[2] Rodhiah, Zahrida, Internal performance measurement model for small retailers, Proceedings, Indonesia, [ICONLEE Muhammadiyah Metro Lampung], pp. 43, November 2016.

[3] M. Munizu, Pengaruh faktor-faktor eksternal dan internal terhadap kinerja usaha mikro dan kecil (UMK) di Sulawesi Selatan, Jurnal Manajemen dan Kewirausahaan, Surabaya: Universitas Kristen Petra, vol. 12(1), 2010, pp. 33-41.

[4] R. Kaplan, How the balanced scorecard complements the McKinsey 7-SModel, Strategy \& Leadership, United Kingdom: Emerald, vol. 33(3), 2005, pp. 41-46.

[5] Z. T. Temtime, J. Pansiri, Small business critical succes/failure factors in developing economies: Some evidences from Bostwana, American Journal of Applied Sciences, United States: Science Publications, vol. 1 2004, pp. 18-25,

[6] D. Chen, Research on performance management of Chinese SME, International Journal of Business and Management, Australia: Society for Alliance, Fidelity and Advancement, vol. 6(4), 2011, pp. 263266.

[7] V. Rivai, Human resource Management for Company, Jakarta: Raja Grafindo Persada, 2009.

[8] V. Kellen, Business performance management: At the crossroads of strategy decision-making, Learning and Information Visualization, 2003.

[9] B. S. Chakravarty, Measuring strategic performance, Strategic Management Journal, United States: John Wiley and Sons, vol. 7, 1996, pp. 437-458.

[10] H. Khairuddin, Determining the moderating effect of environment on the bussiness strategy performance relationship in Malaysia SMEs, Journal of Business Strategy, United Kingdom: Emerald, voI. 8, 2001.

[11] C. Fornell, D. F. Larcker, Evaluating structural equation models with unobservable and measurement error, Journal of Marketing Research, United States: American Marketing Association, vol. 18(1), 1981, pp. 39-50. 
[12] Y. Kim, Y. Choi, Strategic types and performances of small firms in Korea, International Small Bussiness Journal, United Kindom: SAGE Publication, vol. 13(1), 1994, pp. 13-25.
[13] J. Lee, D. Miller, Strategy, environment and performance in two technological contexts: Contingency theory in Korea, Organizations Studies, United States: SAGE Publication, vol. 17(5), 1996, pp. 729-750. 